\title{
Role of Total Soluble Sugar, Phenols and Defense Related Enzymes in Relation to Banana Fruit Rot by Lasiodiplodia theobromae [(Path.) Griff. and Maubl.] During Ripening
}

\author{
Kedar Nath ${ }^{1,2 *}$, Solanky KU', Mahatma MK $^{3,4}$, Madhubala ${ }^{2}$ and Rakesh M Swami ${ }^{3}$
}

${ }^{1}$ Department of Plant Pathology, N. M. College of Agriculture, Navsari Agricultural University, Navsari-645039, India ${ }^{2}$ Regional Rice Research Station, Navsari Agricultural University, Vyara 39 4650, India

${ }^{3}$ Department of Plant Molecular Biology and Biotechnology, Navsari Agricultural University, Navsari 39 450, India

${ }^{4}$ Directorate of Groundnut Research, Indian Council of Agricultural Research, P. B. No.5, Junagadh 362 001, India

\begin{abstract}
During storage conditions banana fruits get infected by several fungal diseases like finger rot, fruit rot, crown rot, cigar-end rot and pitting disease etc. Among these diseases fruit rot caused by Lasiodiplodia theobromae [(Path.)Griff. and Maubl.] is most serious post harvest disease under South Gujarat condition and it causes changes in biochemical contents of banana pulp and peel during ripening. Sugar, Phenols Phenylalanine ammonia lyase (PAL), Polyphenol oxidase (PPO) and Peroxidase (POX) are said to play important role in plant disease resistance. Total sugar, phenolic content, phenylalanine-ammonia lyase, polyphenol oxidase and peroxidase activities were determined in infected and uninfected banana fruits during ripening at 0,48 , and $72 \mathrm{~h}$ after incubation. The results showed that total soluble sugar content was increased with the ripening stages but it was decreased in infected fruits as compared to uninfected fruit. Reduction in PAL activity and enhancement in PPO and POX activity may be correlated with reduction of phenol content during ripening stage but it was still increased in infected banana fruits.
\end{abstract}

Keywords: Banana fruit rot; Lasiodiplodia theobromae; Sugar; Phenol; PAL; Polyphenol oxidase; Peroxidase

Abbreviations: PAL: Phenylalanine Ammonia Lyase; PPO: Polyphenol Oxidase; POX: Peroxidase; APMC: Agricultural Produce Market Committee; GMFU: Green Mature Fruit Uninfected; GMFI: Green Mature Fruit Infected; SRFU: Semi-ripe Fruit Uninfected; SRFI: Semi-Ripe Fruit Infected; RFU: Ripe Fruit Uninfected; RFI: Ripe Fruit Infected

\section{Introduction}

Banana (Musa paradisiaca L.), fruit is one of the most important commercial fruit grow all over the world in the tropical and subtropical areas. It can be grown round the year and it is widely cultivated in India. Apart from these it is considered as potential 'Dollar Earning crop'. It is known since the dawn of ancient history as one of the delicious fruit in the world. The ripening is then done artificially in the various ways, such as exposing the bunches to the sun, placing them over a hearth, wrapping them with green leaves and piling them in a heap, storing them in a closed godowns or smoking them or treated with ethylene. The fruit takes 48 to $72 \mathrm{~h}$ to ripening. Banana fruit suffers from many serious diseases such as fruit rot, crown rot, finger rot, cigar-end rot and pitting disease. The most important disease problem of bananas is finger rot as well as fruit rot caused by Lasiodiplodia theobromae in field and storage condition in South Gujarat. Finger rot diseases may involve several fungal species, but the most commonly associated organism is Lasiodiplodia theobromae [1-3]. The genus Lasiodiplodia, $L$. theobromae, is geographically widespread but is most common in the tropics and subtropics regions which are associated approximately with 500 hosts [4]. Biochemical changes observed in carbohydrates are predominant chemical transformations during ripening of climacteric fruit with a decrease in starch and an increase in sugar content during the ripening of most fruits [5]. Banana fruits at the unripe stage have a relatively higher starch content which is almost completely hydrolysed during ripening to simple sugars, glucose, fructose and sucrose [6]. Glucose and fructose are predominant sugars in post-climacteric banana fruits [7]. Transformation of starch to glucose in bananas fruit during ripening [8]. Total sugar content is increased and total phenol decreased in ripe non-spongy fruits. However, in spongy-white pulp caused by Staphylococcus bacteria, a decrease in reducing, non-reducing sugars and total phenol [9]. However, as the spongy tissue affected pulp turned brownish black due to increase Phenolic content over the nonspongy ripe fruits. Polyphenol oxidase has been found in most higher plants, and is responsible for enzymatic browning of raw fruits and vegetables [10]. This reaction is important in food preservation and processing, and generally considered to be an undesirable reaction because of the unpleasant appearance and concomitant development of an off flavour. Peroxidase activity has been very low in unripe non-spongy mango fruits however it is increased by several fold in non-spongy fruits upon ripening. The development of black color indicated changes in phenolics content either by POX or polyphenol oxidase (PPO) enzymes [9]. In the present studies to determined the total sugar and total phenol content and defense related enzymes viz., Phenylalanine ammonia lyase (PAL), Polyphenol oxidase (PPO) and Peroxidase (POX) activity during banana fruit ripening and in relation to banana fruit rot by $L$. theobromae in during storage.

\section{Materials and Methods}

Biochemical studies were determined to post harvest changes in

*Corresponding author: Kedar Nath, Department of Plant Pathology, N. M College of Agriculture, Navsari Agricultural University, Navsari-645039, India, Tel: 02637282 823; E-mail: drkdkushwaha@nau.in

Received February 09, 2015; Accepted May 12, 2015; Published May 16, 2015

Citation: Nath K, Solanky KU, Mahatma MK, Madhubala, Swami RM (2015) Role of Total Soluble Sugar, Phenols and Defense Related Enzymes in Relation to Banana Fruit Rot by Lasiodiplodia theobromae [(Path.) Griff. and Maubl.] During Ripening. J Plant Pathol Microb 6: 299. doi:10.4172/2157-7471.1000263

Copyright: (c) 2015 Nath K, et al. This is an open-access article distributed under the terms of the Creative Commons Attribution License, which permits unrestricted use, distribution, and reproduction in any medium, provided the original author and source are credited. 
Citation: Nath K, Solanky KU, Mahatma MK, Madhubala, Swami RM (2015) Role of Total Soluble Sugar, Phenols and Defense Related Enzymes in Relation to Banana Fruit Rot by Lasiodiplodia theobromae [(Path.) Griff. and Maubl.] During Ripening. J Plant Pathol Microb 6: 299. doi:10.4172/2157-7471.1000299

uninfected and infected banana fruit with fungus in storage. The isolate of the entophytes fungus Lasiodiplodia theobromae (Griff. and Maubl.) was identified on cultural and morphological characters were studied on PDA medium. The isolate was identified as L. theobromae with the help of illustrated genera of imperfect fungi [11]. The identification of isolate has been confirmed by mycologist, Agharkar Research Institute. Pune (No.3/426-2008), India. Isolate was cultured on potato dextrose agar (PDA) medium and spore suspensions were prepared by washing the surface of 15 days cultures on petriplates with sterile distilled water. The spore suspension was adjusted in sterile water at $10^{6} / \mathrm{ml}$ by using haemocytomere and used as inoculum. The banana fruits (cv. Grand naine) at three different stage i.e., mature green fruits, semi-ripe fruits and ripe fruits were obtained from stock holder at APMC, Navsari. The fruits were surface disinfected with $2 \%$ sodium hypochlorite for $2 \mathrm{~min}$., rinse with two times with sterile distilled water than dried under ceiling fan for an hour and then fruits were infected with spore suspension @ $0.2 \mathrm{ml}$ in each fruit by injection at tip end region. Five fruits in each replication at each stages are infected and maintained three replication in same. Infected and uninfected fruits were kept separately into plastic tray $(15 \times 25 \mathrm{~cm}$ size $)$ then covered with plastic sheet and incubated at room temperature. Biochemical analysis of pulp and pericarp from infected and uninfected banana fruits were separately determined at 0 , 48 and $72 \mathrm{~h}$ after incubation.

Samples were collected from healthy and rotted fruits with pulp and pericarp at three different ripening stage. The samples were either used immediately or kept frozen in liquid nitrogen and stored at $-20^{\circ} \mathrm{C}$ until further use for analysis of biochemical constituents viz., total sugar, phenol content and defense related enzymes such as Phenylalanine ammonia lyase (PAL), Polyphenol oxidase (PPO) and peroxidase assay in relation to disease development.

\section{Total soluble sugar content}

Homogenized pulp with pericarp $(100 \mathrm{mg})$ were extracted with $5 \mathrm{ml}$ of $80 \%$ ethanol and centrifuged at $3000 \mathrm{rpm}$ for 10 minutes. Extraction was repeated 3 times with $80 \%$ ethanol and supernatants were collected into $25 \mathrm{ml}$ volumetric flasks. Final volume of the extract was made to $25 \mathrm{ml}$ with $80 \%$ ethanol. The extract $(0.3 \mathrm{ml})$ was pipetted from each treatment into separate test tubes, and then tubes were placed in to boiling water bath for 3 minutes to evaporate the ethanol. One $\mathrm{ml}$ of MillQ water and $4 \mathrm{ml}$ of $0.2 \%$ anthrone reagent $(200 \mathrm{mg}$ in $100 \mathrm{ml} \mathrm{H}_{2} \mathrm{SO}_{4}$ ) were added in each test tube and placed in ice cold water. Reagent blank was prepared by adding $1 \mathrm{ml}$ of distilled water and $4 \mathrm{ml}$ of anthrone reagent. The intensity of colour was read at 600 $\mathrm{nm}$ on spectrophotometer. A standard curve was prepared using $10 \mathrm{mg}$ glucose per $100 \mathrm{ml}$ distilled water [12].

Total soluble sugar $(\mathrm{mg} / \mathrm{g})=$ Sample O.D $\times$ Standard O.D. $\times$ Dilution factor

\section{Extraction and estimation of total phenolic compounds}

One gram of fruit tissue (pulp with pericarp) homogenized in a pre-chilled mortar and pestle in $10 \mathrm{ml}$ of 80 per cent methanol and the extracts left for $24 \mathrm{~h}$ at room temperature before centrifuge at 15,000 $\mathrm{rpm}$ for 10 minutes [4]. One $\mathrm{ml}$ methanolic extract was added to $5 \mathrm{ml}$ of distilled water and $250 \mu \mathrm{L}$ of Foline-ciocalteu reagent and the solution was kept at $25^{\circ} \mathrm{C}$ for $3 \mathrm{~min}$. Then $1 \mathrm{ml}$ of a saturated solution of $\mathrm{Na}_{2} \mathrm{Co}_{3}$ (20 per cent solution of $\mathrm{Na}_{2} \mathrm{Co}_{3}$ ) and $1 \mathrm{ml}$ of distilled water were added and the mixture were incubated for $1 \mathrm{~h}$ at $25^{\circ} \mathrm{C}$. The absorption of the developed blue color was measured using spectrophotometer at 725 $\mathrm{nm}$ of single wavelength. The total phenol content was calculated by comparison with a standard curve obtained from using pyrocatachol ranging between $0-25 \mu \mathrm{g}$ concentration.
The amount of phenols present in the sample was calculated as below formula.

Phenol $(\mathrm{mg} / \mathrm{g})=$ Sample O.D $\times$ Standard O.D. $\times$ Dilution factor

\section{Defense related enzymes}

Phenylalanine ammonia lyase (PAL): Three hundred milligram of fruit tissue homogenized in a pre-chilled mortar and pestle in $3 \mathrm{ml}$ of extraction buffer containing $50 \mathrm{mM}$ borare-HCL buffer $(\mathrm{pH} \mathrm{8.5)}$ ) and 0.04 per cent $\beta$-mercaptoethanol. The homogenate was centrifuge at $10,000 \mathrm{rpm}$ for $15 \mathrm{~min}$. at $4^{\circ} \mathrm{C}$. The clear supernatant was used as the enzyme source for Phenylalanine ammonia lyase assay $[13,14]$.

The reaction mixture containing $3.0 \mathrm{ml}$ of $0.1 \mathrm{M}$ sodium borate buffer ( $\mathrm{pH} 8.8$ ), $0.5 \mathrm{ml}$ of $0.1 \mathrm{M}$ phenylalanine (dissolved in $0.1 \mathrm{M}$ sodium borate buffer, $\mathrm{pH}$ 8.8). The reaction was initiated by the addition of $0.1 \mathrm{ml}$ enzyme extract. The tubes were incubated at $37^{\circ} \mathrm{C}$ for $2 \mathrm{~h}$. The blank was also set with substrate (containing $3.0 \mathrm{ml}$ of 0.1 $\mathrm{M}$ sodium borate buffer, $\mathrm{pH} 8.8$ and $0.5 \mathrm{ml}$ of $0.1 \mathrm{M}$ phenylalanine). The O.D. read at $290 \mathrm{~nm}$ after $2 \mathrm{~h}$. The enzyme activity was expressed as $\mathrm{U} / \mathrm{h} / \mathrm{g}$ protein.

Polyphenol oxidase (PPO): Three hundred milligram of fruit tissue were grounded with a pre-chilled mortar and pestle in $3 \mathrm{ml}$ of 0.1 $\mathrm{M}$ sodium phosphate buffer, $\mathrm{pH}$ 6.0. The homogenate was centrifuge at $10,000 \mathrm{rpm}$ for $15 \mathrm{~min}$. at $4^{\circ} \mathrm{C}$. The clear supernatant was used for PPO activity assay. The reaction mixture contained $2.9 \mathrm{ml}$ of catechol (0.01 $\mathrm{M}$ catechol in $10 \mathrm{mM}$ phosphate buffer, $\mathrm{pH} 6.0$ ) and reaction was initiated by the addition of $0.1 \mathrm{ml}$ enzyme extract. The changes in the colour due to the oxidized catechol was read at $490 \mathrm{~nm}$ for one minute at an interval of 15 seconds. The enzyme activity was expressed as change in O.D./min/g protein [15].

Peroxidase (POX): The banana fruit tissue $(1 \mathrm{~g})$ was homogenized in a pre-chilled mortar and pestle in $2 \mathrm{ml}$ of $0.1 \mathrm{M}$ phosphate buffer, $\mathrm{pH}$ 7.0 at $4^{\circ} \mathrm{C}$. The homogenates were centrifuged at $12,000 \mathrm{rpm}$ at $4^{\circ} \mathrm{C}$ for $15 \mathrm{~min}$. The supernatant was used as enzyme source for POX activity assay. The reaction mixture consisted $2 \mathrm{ml}$ of $50 \mathrm{mM}$ phosphate buffer (pH7.0) and $0.1 \mathrm{mM}$ EDTA, $10 \mathrm{mM}$ guaiacol $450 \mu \mathrm{l}, 10 \mathrm{Mm} \mathrm{H}_{2} \mathrm{O}_{2}$ $450 \mu \mathrm{l}$ and $100 \mu \mathrm{l}$ enzyme extract. POX activity was determined in the homogenates by measuring the changes in absorbance at $420 \mathrm{~nm}$ due to the formation of tetraguaiacol $\left(\varepsilon=26.6 \mathrm{mM}^{-1} \mathrm{~cm}^{-1}\right)$ in a reaction mixture were recorded at 15 seconds intervals for 1 minute. The enzyme activity was expressed as changes in the absorbance of the reaction mixture $\min ^{-1} \mathrm{~g}^{-1}$ on fresh weight basis [16].

\section{Results and Discussion}

In this study, the changes in the levels of total sugar and phenol as well as the activities of Phenylalanine ammonia lyase (PAL), polyphenol oxidase (PPO) and peroxidase (POX) enzymes during banana fruit ripening and fruit rot disease development were determined.

\section{Total soluble sugar}

In presented result, showed that the total soluble sugar varied in uninfected and infected banana fruits with $L$. theobromae at different ripening stages. The total soluble sugar content was increased with ripening in infected as well as uninfected banana fruits, but it was lower in semi ripe and ripe infected fruits than uninfected fruits after 48 and $72 \mathrm{~h}$ of incubation. Total soluble sugar content was higher $(85.84 \mathrm{mg} / \mathrm{g}$ fresh weight) in ripe fruits while lowest $(2.01 \mathrm{mg} / \mathrm{g}$ fresh weight) in green mature fruits at initial time. Total sugar content was increased in the beginning of the fruit ripening with increased of storage period. 
Citation: Nath K, Solanky KU, Mahatma MK, Madhubala, Swami RM (2015) Role of Total Soluble Sugar, Phenols and Defense Related Enzymes in Relation to Banana Fruit Rot by Lasiodiplodia theobromae [(Path.) Griff. and Maubl.] During Ripening. J Plant Pathol Microb 6: 299. doi:10.4172/2157-7471.1000299

Page 3 of 6

It was higher $(211.57 \mathrm{mg} / \mathrm{g}$ fresh weight) in ripe uninfected fruits and still further decreased $(203.99 \mathrm{mg} / \mathrm{g}$ fresh weight) in infected fruits and lowest in uninfected green mature fruits after $72 \mathrm{~h}$ of storage (Figure 1a). Total soluble sugar content was increase in green mature infected fruits ( 9.07 fold) followed by green mature uninfected fruits (4.62 fold). However in semi ripe and ripe it was increased with 3.58 and 2.46 fold respectively after $72 \mathrm{~h}$ of storage (Table 1 ). These results are corroborated with earlier worker found transformation of starch to glucose in bananas during ripening $[6,8]$. However, higher starch content in unripe banana fruits completely hydrolysed during ripening to simple sugars, glucose, fructose and sucrose. Catalase activity is decrease in healthy as well as in the fruits pulp infected by Aspergillus flavus and increase invertase activity which helped in accumulation of soluble sugars making pulp more soft [17]. Accumulation of sugar neat the infection court which increase the pectolytic and cellulolytic enzymes activity which are essential for pathogenesis and play key role in disintegration of tissue which caused pulp rot development Similarly total sugar content was in results indicated that decreasing of total soluble sugar content in infected fruits related with disease development because it utilized by the pathogen as food for their
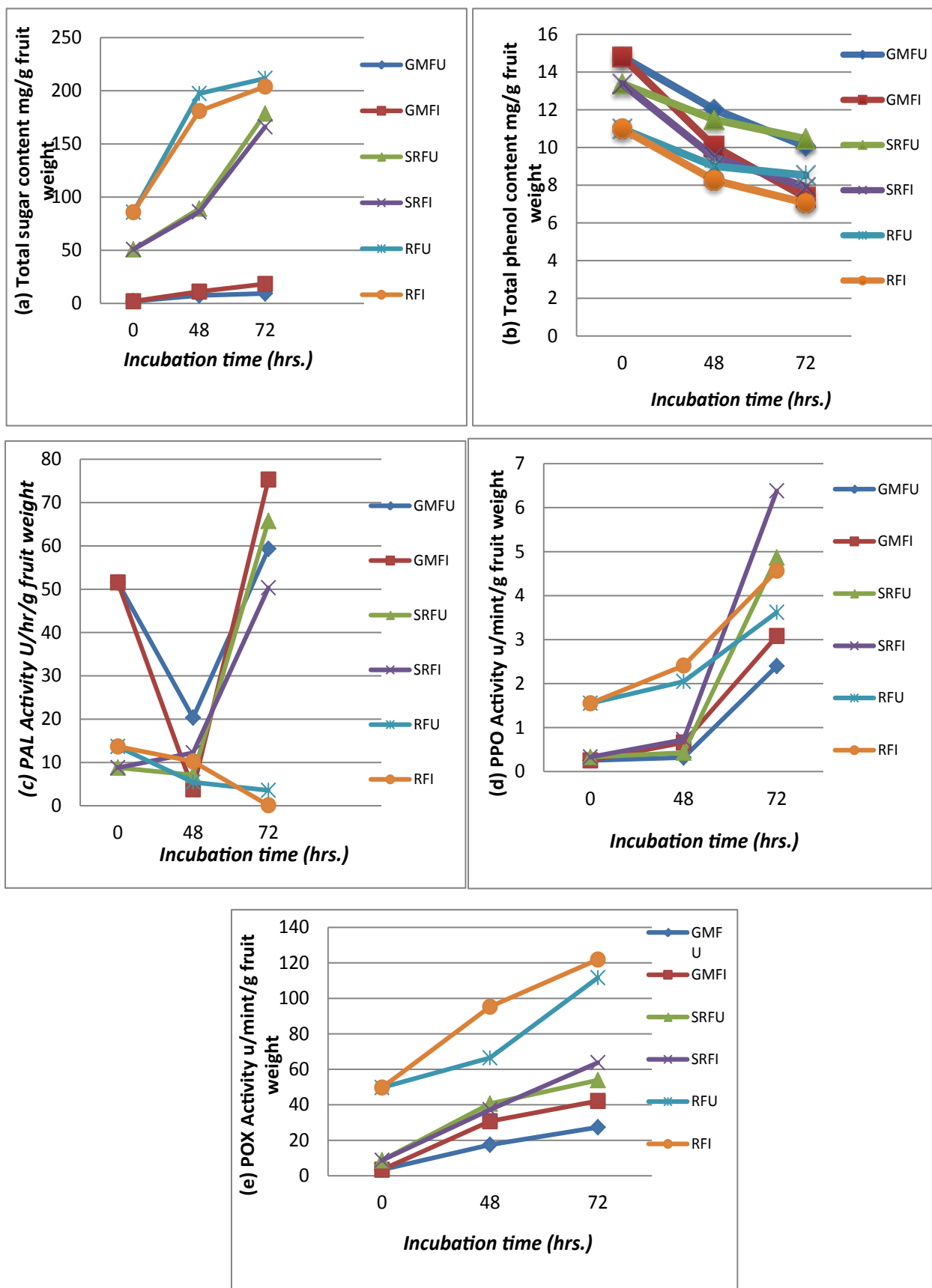

Figure 1: Biochemical changes in infected and uninfected banana fruit (Vart. Grand Naine), (a) Total sugar content $\mathrm{mg} / \mathrm{g}$ fruit weight, (b) Total phenol content mg/g fruit weight, (c) PAL Activity U/hr./g fruit weight, (d) PPO Activity U/mint./g fruit weight, (e) POX Activity U/mint/g fruit weight. 
Citation: Nath K, Solanky KU, Mahatma MK, Madhubala, Swami RM (2015) Role of Total Soluble Sugar, Phenols and Defense Related Enzymes in Relation to Banana Fruit Rot by Lasiodiplodia theobromae [(Path.) Griff. and Maubl.] During Ripening. J Plant Pathol Microb 6: 299. doi:10.4172/2157-7471.1000299

Page 4 of 6

(a) Total phenol content $\mathrm{mg} / \mathrm{g}$ fruit weight

\begin{tabular}{|c|c|c|c|c|c|c|c|c|}
\hline \multirow{2}{*}{ Sr. No. } & \multirow{2}{*}{ Sample } & 0 hrs. & \multicolumn{2}{|c|}{$48 \mathrm{~h}$ after } & \multicolumn{4}{|c|}{$72 \mathrm{~h}$ after } \\
\hline & & Uninfected & Uninfected & Infected & Uninfected & Infected & Fold * & Fold** \\
\hline 1 & Green mature fruits & $2.016 \pm 0.79$ & $7.514 \pm 0.79$ & $11.176 \pm 0.59$ & $9.327 \pm 0.34$ & $18.28 \pm 0.23$ & +4.62 & +9.07 \\
\hline 2 & Semi ripe fruits & $50.819 \pm 2.90$ & $89.139 \pm 0.79$ & $86.14 \pm 1.32$ & $178.54 \pm 2.01$ & $166.14 \pm 5.40$ & +3.58 & +3.27 \\
\hline 3 & Ripe fruits & $85.841 \pm 1.06$ & $197.32 \pm 2.87$ & $181.05 \pm 0.99$ & $211.57 \pm 56.42$ & $203.99 \pm 5.21$ & 2.46 & +2.38 \\
\hline
\end{tabular}

(b) Total sugar content $\mathrm{mg} / \mathrm{g}$ fruit weight

\begin{tabular}{|c|c|c|c|c|c|c|c|c|}
\hline \multirow{2}{*}{ Sr. No } & \multirow{2}{*}{ Sample } & \multirow{2}{*}{$\begin{array}{c}0 \text { hrs. } \\
\text { Uninfected }\end{array}$} & \multicolumn{2}{|c|}{$48 \mathrm{~h}$ after } & \multicolumn{4}{|c|}{$72 \mathrm{~h}$ after } \\
\hline & & & Uninfected & Infected & Uninfected & Infected & Fold & Fold \\
\hline 1 & Green mature fruits & $14.802 \pm 0.26$ & $12.028 \pm 0.72$ & $10.05 \pm 0.53$ & $10.065 \pm 1.08$ & $7.358 \pm 1.19$ & -1.47 & -2.01 \\
\hline 2 & Semi ripe fruits & $13.375 \pm 1.43$ & $11.483 \pm 1.07$ & $9.476 \pm 0.16$ & $10.456 \pm 0.11$ & $7.911 \pm 0.07$ & -1.28 & -1.69 \\
\hline 3 & Ripe fruits & $10.984 \pm 0.39$ & $9.008 \pm 0.65$ & $8.266 \pm 0.59$ & $8.522 \pm 0.91$ & $7.0547 \pm 0.73$ & -1.29 & -1.56 \\
\hline \multicolumn{9}{|c|}{ (c) PAL Activity U/hr/g fruit weight } \\
\hline \multirow{2}{*}{ Sr. No } & \multirow{2}{*}{ Sample } & 0 hrs. & \multicolumn{2}{|c|}{$48 \mathrm{~h}$ after } & \multicolumn{4}{|c|}{$72 \mathrm{~h}$ after } \\
\hline & & Uninfected & Uninfected & Infected & Uninfected & Infected & Fold & Fold \\
\hline 1 & Green mature fruits & $51.551 \pm 3.44$ & $20.331 \pm 2.70$ & $3.777 \pm 0.77$ & $59.328 \pm 4.91$ & $75.326 \pm 2.0$ & +1.15 & +1.61 \\
\hline 2 & Semi ripe fruits & $8.777 \pm 0.34$ & $7.1103 \pm 1.0$ & $12.221 \pm 1.29$ & $65.738 \pm 6.37$ & $50.328 \pm 3.28$ & +4.81 & +3.68 \\
\hline 3 & Ripe fruits & $13.666 \pm 1.39$ & $5.444 \pm 0.27$ & $10.221 \pm 1.05$ & $3.555 \pm 3.01$ & $6.11 \pm 1.17$ & +3.27 & +1.04 \\
\hline \multicolumn{9}{|c|}{ (d) PPO Activity u/mint/g fruit weight } \\
\hline \multirow{2}{*}{ Sr. No } & \multirow{2}{*}{ Sample } & 0 hrs. & \multicolumn{2}{|c|}{$48 \mathrm{~h}$ after } & \multicolumn{4}{|c|}{$72 \mathrm{~h}$ after } \\
\hline & & Uninfected & Uninfected & Infected & Uninfected & Infected & Fold & Fold \\
\hline 1 & Green mature fruits & $0.253 \pm 0.13$ & $0.319 \pm 0.05$ & $0.660 \pm 0.23$ & $2.398 \pm 1.03$ & \pm 0.28 & +9.48 & +12.17 \\
\hline 2 & Semi ripe fruits & $0.330 \pm 0.09$ & $0.429 \pm 0.10$ & $0.726 \pm 0.10$ & $4.862 \pm 1.35$ & $6.380 \pm 0.46$ & +14.73 & +19.33 \\
\hline 3 & Ripe fruits & $1.551 \pm 0.31$ & $2.046 \pm 0.41$ & $2.409 \pm 0.50$ & $3.619 \pm 1.02$ & $4.565 \pm 1.57$ & +2.33 & +2.94 \\
\hline \multicolumn{9}{|c|}{ (e) POX Activity u/mint/g fruit weight } \\
\hline \multirow{2}{*}{ Sr. No } & \multirow{2}{*}{ Sample } & 0 hrs. & \multicolumn{2}{|c|}{$48 \mathrm{~h}$ after } & \multicolumn{4}{|c|}{$72 \mathrm{~h}$ after } \\
\hline & & Uninfected & Uninfected & Infected & Uninfected & Infected & Fold & Fold \\
\hline 1 & Green mature fruits & $3.4176 \pm 0.23$ & $17.468 \pm 1.73$ & $30.759 \pm 1.87$ & $27.341 \pm 1.34$ & $42.151 \pm 4.84$ & +8.0 & +12.33 \\
\hline 2 & Semi ripe fruits & $8.734 \pm 0.74$ & $40.632 \pm 2.73$ & $37.214 \pm 2.40$ & $53.923 \pm 3.95$ & $63.796 \pm 3.98$ & +6.17 & +7.30 \\
\hline 3 & Ripe fruits & $49.746 \pm 3.41$ & $66.454 \pm 4.21$ & $95.314 \pm 5.40$ & $111.64 \pm 6.98$ & $121.90 \pm 4.12$ & +2.24 & +2.45 \\
\hline
\end{tabular}

Table 1: Activity of total soluble sugar, phenols and defense related enzymes in relation to banana fruit rot by Lasiodiplodia theabromae [(Path.) Griff. and Maubl.] and ripening stages. Mean of three replication, ${ }^{*}$ Change over time in uninfected, ${ }^{* *}$ Change over time in uninfected on infected.

growth and development. $[5,7,18,19]$. Total sugars also play a major role in disease resistance since sugars are the precursors for the synthesis of phenolics and phytoalexins which suppress the pectolytic and cellulolytic enzymes that are essential for pathogenesis.

\section{Total phenols}

Phenolic compounds are the most important group implicated in both constitutive and induced resistance and a distinct correlation between the degree of plant resistance and phenolics present in plant tissue has been demonstrated.

The phenol content was decreased with increasing storage period in uninfected and further decreased in infected in all three stages. Total phenol content was higher in green mature fruits $(14.80 \mathrm{mg} / \mathrm{g}$ fruit weight) followed by semi- ripe $(13.38 \mathrm{mg} / \mathrm{g}$ fruit weight) and ripe fruits $(10.98 \mathrm{mg} / \mathrm{g}$ fruit weight) at initial period. Lowest total phenol content was observed in ripened infected fruits $(7.05 \mathrm{mg} / \mathrm{g}$ fruit weight) followed by semi-ripe and green mature infected fruits with 7.91 and $7.38 \mathrm{mg} / \mathrm{g}$ fruit weight as compared to uninfected fruits after $72 \mathrm{~h}$ of incubation (Figure 1b). Highest phenol content was decreased in mature green fruits ranging from 14.80 to $7.35 \mathrm{mg} / \mathrm{g}$ fruit weight during ripening and it was further still decreased in infected same fruit. However, phenol content was least decreased in ripe fruits more or less similar in uninfected and infected. The total phenol contents change over the period it was more decreased in infected mature green fruits with -2.01 fold but in uninfected same fruit it increased with -1.47 fold after $72 \mathrm{~h}$ of incubation. In semi ripe fruits -1.69 fold changes over infected fruits was observed and further -1.28 fold change increased over uninfected fruits. However, total phenol content was decreased as the fruits ripened, and in rotted fruits decreased further. Our results are consistence with earlier workers, found that Phenolic content was significantly decreased in sapota fruit infected by Aspergillus niger [20]. This suggested that during ripening in healthy fruits phenol synthesis is decreased. During mango fruits ripening, the initial total phenolics content of unripe non-spongy fruits decreased by about 30 per cent [9]. From these results suggested that decrease phenol content during ripening will lead to fruit rot disease development.

\section{PAL activity}

The results demonstrated that enzyme activity was higher in green mature infected fruits ( 75.33 Units $^{-1} \mathrm{~g}^{-1}$ protein) than uninfected $(59.33$ Units $\mathrm{h}^{-1} \mathrm{~g}^{-1}$ protein) which was decreased in ripe infected fruits $(9.11$ Units $\mathrm{h}^{-1} \mathrm{~g}^{-1}$ protein) and uninfected (3.56 Units $\mathrm{h}^{-1} \mathrm{~g}^{-1}$ protein) after 72 $\mathrm{h}$ of storage (Figure 1c). These results suggests that constitutive level of PAL was higher in green mature fruits then decreased with the ripening stages. It was first decrease then increased in infected green mature fruits. The PAL activity was increased after 24 and $72 \mathrm{~h}$ storage in green mature and semi-ripe fruits irrespective of infection, while decreased in ripe fruits as compared to initial period. Moreover, PAL activity was 4.81 fold higher in uninfected semi ripe fruits as compared to infected semi ripe fruits after $72 \mathrm{~h}$ of incubation (Table 2). Our results collaborated with recently workers reported activities of the defense related enzymes phenylalanine ammonia Lyase (PAL) was enhanced in benzothiadiazole (BTH) and in Methyl jasmonate (MeJA) treated banana fruits irrespective of inoculated with Colletotrichum musae or 
Citation: Nath K, Solanky KU, Mahatma MK, Madhubala, Swami RM (2015) Role of Total Soluble Sugar, Phenols and Defense Related Enzymes in Relation to Banana Fruit Rot by Lasiodiplodia theobromae [(Path.) Griff. and Maubl.] During Ripening. J Plant Pathol Microb 6: 299. doi:10.4172/2157-7471.1000299

Page 5 of 6

\begin{tabular}{|c|c|c|c|c|c|c|c|}
\hline \multirow{3}{*}{ Sr. No. } & \multirow{3}{*}{ Biochemical activity } & \multicolumn{6}{|c|}{ Activity folds change over $72 \mathrm{~h}$ of incubation } \\
\hline & & \multicolumn{2}{|c|}{ Green mature fruits } & \multicolumn{2}{|c|}{ Semi ripe fruits } & \multicolumn{2}{|c|}{ Ripe fruits } \\
\hline & & uninfected & infected & uninfected & infected & uninfected & infected \\
\hline 1 & Total phenol content $\mathrm{mg} / \mathrm{g}$ fruit weight & -1.47 & -2.01 & -1.28 & -1.69 & -1.29 & -1.56 \\
\hline 2 & Total sugar content mg/g fruit weight & +4.62 & +9.07 & +3.58 & +3.27 & +2.46 & +2.38 \\
\hline 3 & $\begin{array}{c}\text { PAL activity } \\
\text { U/hr./g fruit weight }\end{array}$ & +1.15 & +1.61 & +4.81 & +3.68 & +3.27 & +1.04 \\
\hline 4 & $\begin{array}{c}\text { PPO activity } \\
\mathrm{U} / \text { mint./g fruit weight }\end{array}$ & +9.48 & +12.17 & +14.73 & +19.33 & +2.33 & +2.94 \\
\hline 5 & $\begin{array}{c}\text { POX activity } \\
\mathrm{U} / \mathrm{mint} / \mathrm{g} \text { fruit weight }\end{array}$ & +8.0 & +12.33 & +6.17 & +7.30 & +2.24 & +2.45 \\
\hline
\end{tabular}

Table 2: Activity of total soluble sugar, phenol and defense related enzymes in banana fruits uninfected and infected by $L$. theobromae at different ripening stages.

not [21]. The results suggest that post harvest decay in banana fruits can be controlled by BTH and MeJA. PAL is induced by stress such as wounding and fungal attack $[22,23]$. From this results suggested that enhanced the PAL activities was correlated with pathogenesis.

\section{PPO activity}

PPO activity was found lower in green mature infected and uninfected fruits at all storage period of determination although, the enzyme activity of uninfected (2.4 Units $\mathrm{min}^{-1} \mathrm{~g}^{-1}$ protein) was more or less similar to infected (3.08 Units $\mathrm{min}^{-1} \mathrm{~g}^{-1}$ protein) after $72 \mathrm{~h}$ of storage (Figure 1d). At initial period of incubation the PPO activity was (1.55 Units $\mathrm{min}^{-1} \mathrm{~g}^{-1}$ protein) higher in ripe fruits as compared to semiripe fruits ( 0.33 Units $\mathrm{min}^{-1} \mathrm{~g}^{-1}$ protein) andt it was increased with the incubation period in both infected and uninfected fruits. However, in uninfected semi ripe fruits PPO activity was increased about 14.73 fold after $72 \mathrm{~h}$ incubation, while in infected semi-ripe fruits it was higher ( 19.33 fold). PPO activity was increased with the ripening stages and it was further increased in infected fruits of all stages but highest activity found in infected semi ripe fruit then in uninfected fruits. Our results suggests that PPO activity was increased beginning the fruit ripening and further increased with the increasing storage time but increment was more pronounced in the inoculated fruits. These results are consistant with earlier workers they also observed increased polyphenol oxidase in banana fruit infected by Botryodiplodia theobromae [24]. Polyphenol oxidase and peroxidase activity gradually decreased during the development of the fruits followed then by an increase during the ripening period. The level of sugar gradually increased during fruit development and ripening which affects the taste of medlar fruits $[21,25]$. These observations suggest that the increase in PPO and POD activities as well as in sugar and protein contents has an important role in reducing the astringent taste of the fruits. Our results showed that PPO activity was induced during pathogenesis of L. theobromae.

\section{POX activity}

POX activity was found higher in ripe fruits $(49.75-121.9 \mu \mathrm{mol}$ guaiacol $\mathrm{min}^{-1} \mathrm{~g}^{-1}$ protein) than in semi ripe fruits $(8.73-63.8 \mu \mathrm{mol}$ guaiacol $\mathrm{min}^{-1} \mathrm{~g}^{-1}$ protein) up to $72 \mathrm{~h}$ of storage (Figure 1e). The POX activity was enhanced after infected with $L$. theobromae in all ripening stages. The degree of increase in infected green mature, semi ripe and ripe was $12.33,7.30$ and 2.45 fold higher respectively than uninfected fruits (Table 1). Our results showed that POX activity was enhanced during host-pathogen interaction. These results are corroborated with earlier findings [26] indicated the green and red pepper fruit with Colletotrichum gloeosporiodes, the peroxidase genes were strongly activated in the green fruit by anthracnose disease but not in red fruit resistant to anthracnose disease. These results suggest that the peroxidase genes may be inducible during the pathogenesis of the anthrachose disease rather than in the disease resistance response. Similar results were observed in banana fruit infected by Botryodiplodia theobromae [24]. Change in peroxidase levels in mango fruits at various stages of ripening. The development of black color in ripened fruits indicated increased activity of POX or PPO enzymes $[9,21]$. In present study reduction in PAL activity and enhancement in PPO and POX activity in ripe fruits may be correlated with reduction of phenol content in ripe fruits. Higher activity of these enzymes in inoculated fruits as compared to uninoculated fruits reflects the invasion of pathogen.

Polyphenol oxidase and Peroxidase activity gradually decreased during the development of the fruits followed then by an increase during the ripening period [25]. These observations suggest that the increase in PPO and POD activities as well as in sugar and protein contents has an important role in reducing the astringent taste of the medlar fruits. Changes in peroxidase levels at various stages of ripening and spongy mango fruits. In unripe non-spongy fruits, a very low POX activity was observed. POX activity increased by several fold in nonspongy fruits upon ripening, however, in spongy fruits there was a further 1.5-fold increase in activity over that in ripe nonspongy fruits. The development of black color indicated changes in phenolics content either by POX or PPO enzymes [9].

\section{Summary and Conclusion}

Total sugar was higher in uninfected ripe fruits and decreased in fruits infected with $L$. theobromae and lowest in uninfected green mature fruits after $72 \mathrm{~h}$ of storage. A nine-fold increase in total sugar content was observed in green mature inoculated fruits followed by green mature uninfected and semi ripe fruits. Total phenol content was higher in green mature fruits than decline in semi ripe and ripe fruits at initial time. The phenol content was decreased with increasing storage period in uninfected and further decreased infected in all three stages.

Phenylalanine ammonia lyase (PAL) activity was higher in green mature infected fruits than uninfected which was decreased in ripe infected and uninfected fruits after $72 \mathrm{~h}$ of storage. PPO activity of uninfected fruits was more or less similar to infected fruits after $72 \mathrm{~h}$ of storage. However, in uninfected semi ripe fruits PPO activity was increased about 14.72 fold after $72 \mathrm{~h}$ of incubation, while in infected semi-ripe fruits it was higher (19.33 fold) as compared to mature green and ripe fruits. POX activity was found higher in ripe fruits than in semi ripe fruits up to $72 \mathrm{~h}$ of incubation. The POX activity enhanced after inoculation with $L$. theobromae in all ripening stages. The degree of increase in infected green mature, semi ripe and ripe was $12.33,7.30$ and 2.45 fold higher respectively than uninfected fruits.

During ripening stages the level of total phenol gradually decreased in both infected and uninfected fruits, but it was more decreased in infected green mature fruits. The level of total sugar gradually increased during fruit ripening. PAL activity decreased in ripening stages but it increased in infected fruits. PPO and POD activity gradually increased 
Citation: Nath K, Solanky KU, Mahatma MK, Madhubala, Swami RM (2015) Role of Total Soluble Sugar, Phenols and Defense Related Enzymes in Relation to Banana Fruit Rot by Lasiodiplodia theobromae [(Path.) Griff. and Maubl.] During Ripening. J Plant Pathol Microb 6: 299. doi:10.4172/2157-7471.1000299

in the ripening stage but degree of increase was higher in infected fruits. Reduction in PAL activity and enhancement in PPO and POX activity may be correlated with reduction of phenol content in ripening stages but it still increased in infected fruits. PAL, PPO and POX activity may be induced during pathogenesis of $L$. theobromae and stress during ripening.

\section{Acknowledgments}

The expert technical contributions of Dr. K.U. Solanky and Dr. Mahesh Kumar Mahatma are gratefully acknowledged. We acknowledged to Prof. and Head, Department of Plant Biotechnology, ASPEE College of Horticulture and Forestry, and Department of plant pathology, Navsari Agricultural University, Navsari, for providing technical assistance. Specially acknowledged to Department of statistic for statistical analyses.

\section{References}

1. Goos RD, Cox EA, Stotsky G (1961) Botryodiplodia theobromae and its association with Musa species. Mycologia 53: 262-277.

2. Wade NL, Kavanagh EE, Sepiah M (1993) Effects of modified atmosphere storage on banana postharvest diseases and the control of bunch main-stalk rot. Postharvest Biology and Technology 3: 143-154.

3. Ploetz R (1998) Banana disease in the subtropics: a review of their importance distribution and management. Acta Horti 490: 263-276.

4. Punithalingam E (1980) Plant diseases attributed to Botryodiplodia theobromae Pat. J Cramer Vaduz 42-43

5. Biale JB (1964) Growth, Maturation, and Senescence in Fruits: Recent knowledge on growth regulation and on biological oxidations has been applied to studies with fruits. Science 146: $880-888$.

6. Biale JB (1960) The post-harvest biochemistry of tropical and subtropical fruits Adv Food Res 10: 293.

7. Lizana LA (1976) Quantitative evaluation of sugars in banana fruit ripening at normal to elevated temperatures. Acta Hortic 57: 163.

8. Terra NN, Garcica E, Lajolo FM (1983) Starch sugar transformation during banana ripening. J Food Sci 48: 1097

9. Janave MT (2008) Biochemical changes induced due to Staphylococcal infection in spongy alphonso mango (Mangifera indica L.) fruits. J Crop Sci Biotech 10: 167-174.

10. Mathew AG, Parpia HAB (1971) Food browning as a polyphenol reaction. Adv Food Res 19: 75-145.

11. Barnett HL, Hunter BB (1972) Illustrated genera of imperfect fungi. (3rdedn) Mixneapolis, Burgess Pub, p. 188
12. Franscistt W, David FB, Robert MD (1971) The estimation of the total soluble carbohydrate in cauliflower tissue. Experiment in plant phyisiology, Van, Nostrand. Reinhold Camp, New York, p. 16.

13. Swain T, Hills WE (1959) The phenolic constituents of Prunus domestica I. the quantitative analysis of phenolic constituents. J Sci Food Agri 10: 63-68.

14. Mahadevan A, Sridhar R (1996) In: Methods in physiological plant pathology. Kalyani Publisher.

15. Malik CP, Sing BM (1980) In: Plant Enzymology and Histo-Enzymology Kalyani Publishers New Delhi, p. 286.

16. Hammerschmidt R, Nuckles EM, Kuc J (1982) Association of enhanced peroxidase activity with induced systemic resistance of cucumber to Colletotrichum lagenarium. Physiol Plant Pathol 20: 73-82.

17. Singh R, Saxena VG (1991) Catalase and invertase activity in Banana fruit infected by Aspergillus niger. Indian J mycol PI Pathol 21: 211-212.

18. John M, Robinson M, Karkari SK (1981) Starch and sugar transformation during the ripening of plantains and bananas. J Sci Food Agric 32: 1021

19. Kadioglu A, Yavru I (1998) Changes in the chemical content and polypheno oxidase activity during development and ripening of cherry laurel. Phyton (Horn, Austria) 37: 241-251.

20. Wagh PM, UN Bhale (2012) Changes in phenolic contents of sapota pulp (Achras sapota) due to different isolates of Aspergillus niger. Bioscience Discovery 3: 263-265.

21. Zhu S, Ma B (2007) Benzothiazole or methyl jasmonate induced resistance to colletotrichum musae in harvested banana fruit is related to elevated desense enzyme activities. Hort Sci \& Bio-tech 82: 500-506.

22. Morello JM, Romero MP, Ramo T, MJ Motilva (2005) Evaluation of L-Phenylalanine ammonia-lyase activity and phenolic profi le in olive drupe (Olea europaea L.) from fruit setting period to harvesting time. Plant Science 168: 65-72.

23. Pereyra L, Roura SI, CE Del Valle (2005) Phenylalanine ammonia lyase activity in minimally processed Romaine lettuce. Lebensmittel Wissenschaft und Technologie 38: 67-72.

24. Chakraborty N, Nandi B (1978) Enzyme activity in banana fruits rot by Botrydiplodia theobromae pat. Acta Agrobotanica 31: 41-46.

25. Aydin N, Kadioglu A (2001) Changes in the chemical composition, polypheno oxidase and peroxidase activities during development and ripening of Medlar fruits (Mespilus germanica L.). Bulg. J. Plant Physiol 27: 85-92.

26. Lee SC, Lee YK, Kim KD, BK Hwang (2000) In situ hybridization study of pathogen and organ-dependent expression of a novel thionin gene in pepper (Capsicum annum). Physiol Plantarum 110: 384-392. 